\title{
Determination of optimum irrigation scheduling for sorghum in Benna-Tsemay Woreda, Southern Ethiopia
}

\author{
T.M. Lebiso* and M.M. Mada
}

Received 23 July 2021, Revised 13 November 2021, Accepted 20 December 2021, Published online 31 December 2021

\section{A B S T R A C T}

Scarcity of water is the most severe constraint for sustainable development of agriculture in arid and semi-arid areas. Hence, novel irrigation water application systems need to be developed so that high crop yield and water productivity per unit of land can be increased. Thus, the field experiment was conducted with the objective of determining the effect of different soil moisture depletion levels on yield and water use efficiency of sorghum crop in Benna-Tsemay woreda at Enchete kebele, Southern Ethiopia. The experiment was conducted for two consecutive years (2019-2020). It was arranged in RCBD with three replications and treatment was rated for five levels of available soil moisture depletion (ASMD), where $\mathrm{T}_{1}=60 \%, \mathrm{~T} 2=80 \%, \mathrm{~T}_{3}=100 \%, \mathrm{~T}_{4}=120 \%$, and $\mathrm{T}_{5}=140 \%$ of ASMD. Analysis of variance has shown that yield and water use efficiency of sorghum crop was significantly $(\mathrm{P}<0.05)$ affected by irrigation scheduling. As observed in this study, the most economically attractive and environmentally accepted for small scale farmers with tolerable cost of production and higher net benefit was obtained by application of T3 (100\% ASMD) under conventional furrow irrigation system. Therefore, for this particular sorghum crop (teshale variety), it could be concluded that increased water saving and water productivity through irrigation at 100\% ASMD under conventional furrow irrigation system can solve the problem of water shortage and would ensure the opportunity of further irrigation development in the study area and similar agro-ecology.

Keywords: ASMD, Irrigation scheduling, Sorghum, Water use efficiency

Southern Agricultural Research Institute, Jinka Agricultural Research Center, Irrigation and Drainage Research Program, Jinka, Ethiopia

*Corresponding author's email: tademugoro@gmail.com (T.M. Lebiso)

Cite this article as: Lebiso, T.M. and Mada, M.M. 2021. Determination of optimum irrigation scheduling for sorghum in Benna-Tsemay Woreda, Southern Ethiopia. Int. J. Agril. Res. Innov. Tech. 11(2): 95-102. https://doi.org/10.3329/ijarit.v11i2.57261

\section{Introduction}

In low land areas of Ethiopia, irrigated agriculture is becoming main concern and strongly recognized to ensure the food security, which is taken as a means to increase food production and self-sufficiency of the rapidly increasing population of the country. Accordingly, Ethiopia has planned to irrigate over 5 million hectares of the land with existing water resources (Awulachew et al., 2010). This expansion of irrigated agriculture to feed the ever-increasing population on one hand and the increasing competition for water due to the development of other water use sectors on the other hand necessitated the improvement of water use efficiencies in irrigated agriculture to ensure sustained production and conservation of this limited resource (Mekonen, 2011).

Improving water use efficiency is an important strategy for addressing future water scarcity problem particularly in arid and semi-arid regions (Mdemu et al., 2008). Thus, water productivity is an indicator of agricultural productivity in relation to the crop's consumptive use of water (WDR, 2003). As argued by the Geerts and Raes (2009), and FAO (2010), increasing crop water productivity can be an important pathway for poverty reduction. This would enable growing more food and gaining more benefits with less water thus enhancing the household income.

Water availability is the most limiting factor for crop production in the dry-land areas of Ethiopia. Moreover, lack of crop water requirement studies for major crops had been a challenge for appropriate utilization of scarce water resource in irrigated agriculture and it leads to low water use efficiency through improper irrigation scheduling. Determination of water requirement of the crop, appropriate irrigation scheduling can be designed, which can lead to improvements in 
the yield, income, and water saving. To ensure the highest crop production with the least water use, it is important to know the water requirement of the crops. This improves the efficient and economic use of irrigation water (Wale and Girmay, 2019).

Benna-Tsemay Woreda is one district of South Omo Zone in Southern Region of Ethiopia where due to low and erratic rainfall; chronic drought and water scarcity is observed recurrently and upsetting agricultural productivity. According to AGP-II (2015) survey report, the economy of the district is highly dependent on agriculture (livestock and crop production), which is in turn dependent on the availability of erratic rainfall and scarce water resources. As result, there was competition for water use between inhabitants for livestock as well as crop production. On the other hand, lack of improved small scale irrigation technologies, less irrigation water management practices and inadequate research supports are a major problem for efficient irrigation water use and agricultural production improvement in the area.

Accordingly, in these arid and semi-arid regions where the availability of irrigation water is a limiting factor for crop production, the knowledge of the crop water productivity is imperative. To increase crop water productivity and irrigation water management; proper irrigation scheduling is a key element. The target crop sorghum is one of the major traditional crops grown under irrigation mainly in the arid and semi-arid areas of South Omo Zone. It is the most important and a staple food crop for the people who live in the dry land areas of BennaTsemay woreda, South Omo Zone in South west Ethiopia. Therefore, this study was conducted with the objective of determining the net irrigation requirement and optimum irrigation schedules of sorghum in Benna-Tsemay woreda at Enchete kebele.

\section{Materials and Methods}

\section{Description of the study area}

\section{Location}

The study was conducted at Weyito experimental site of Jinka Agricultural Research Center in Southern Agricultural Research Institute. The site is situated in the eastern part of Benna-Tsemay Woreda at Enchete kebele a distance of $82 \mathrm{~km}$ away from Jinka town, capital of South Omo Zone, Southern Ethiopia. Geographically, the experimental site is located at $5^{\circ} 18^{\prime} 0^{\prime \prime}$ to $5^{\circ} 31^{\prime} 33^{\prime \prime}$ $\mathrm{N}$ latitude and $36^{\circ} 52^{\prime} 30^{\prime \prime}$ to $37^{\circ} 5$ 'o" E longitude, and at an altitude of $550 \mathrm{~m}$ above sea level. Likewise, it is found $668 \mathrm{~km}$ south west of Addis Ababa and about $438 \mathrm{~km}$ west of Hawassa, the capital of Southern Nations Nationalities and Peoples Regional State (Mugoro et al., 2020).

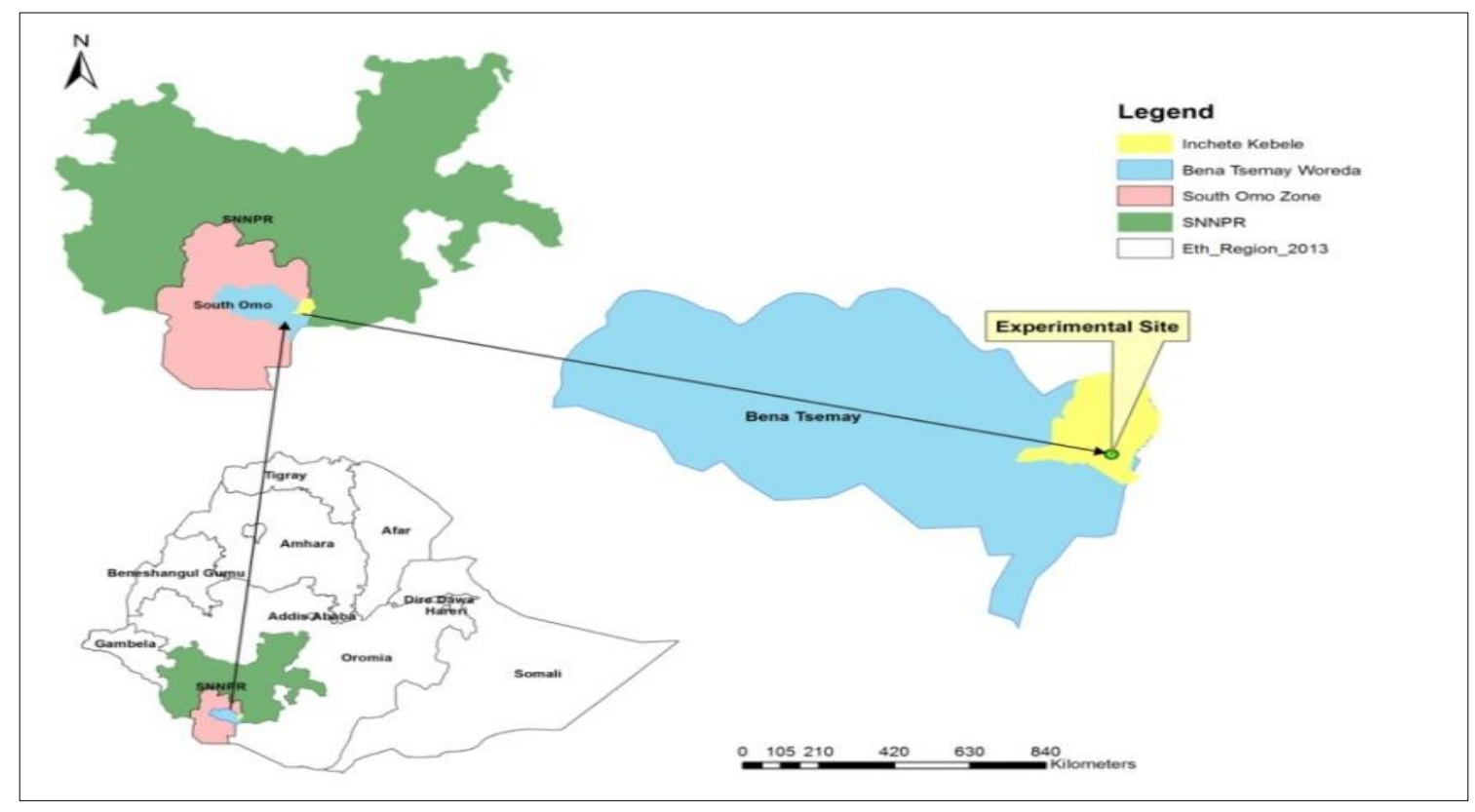

Fig. 1. Experimental site.

\section{Climate and agronomic characteristics}

The rainfall distributions in the area is erratic and uneven with mean annual rainfall ranges from $400 \mathrm{~mm}$ to $1400 \mathrm{~mm}$ and mean annual temperature ranges from $26^{\circ} \mathrm{C}$ to $40^{\circ} \mathrm{C}$. The area has a long dry season from November to the beginning of March, while June and July is a short dry season. Agro-ecologically, the area is classified as hot arid and semi-arid climate, and it is characterized by recurrent water shortage, 
intermittent famine, overgrazing and dry land cultivation (BOFED, 2015). Farmers grow crops twice a year, one during the dry season (March July) by irrigation, the other during the partial rainy season (August - October) by using supplementary irrigation. Major irrigated crops grown in the area includes maize, sorghum, sesame, onion, tomato, cotton and banana (Mugoro et al., 2020).

\section{Experimental design and treatments}

The experiment was done for two consecutive years (2019-2020). It was arranged in randomize complete block design with three replications. The treatment was rated for five levels of soil moisture depletion (ASMD). The recommended allowable soil moisture depletion for sorghum is $55 \%$ of the total available soil moisture that was used as $100 \%$ of ASMD. The rates were $\mathrm{T} 1=60 \%$ ASMD, T2 $=80 \%$ ASMD, T3 $=100 \%$ ASMD, $\mathrm{T}_{4}=$ $120 \%$ ASMD, and $\mathrm{T}_{5}=140 \%$ of ASMD. The total number of plots was fifteen where the area of each plot was $12 \mathrm{~m}^{2}$. The space between plots and replications (blocks) was $1.5 \mathrm{~m}$ and $2 \mathrm{~m}$ respectively, which was used to eliminate the influence of lateral water movement. The space between plants and rows were 15 and $75 \mathrm{~cm}$ respectively. The total area of the experimental field was $480 \mathrm{~m}^{2}$ and the net irrigated plot area of the experiment was $180 \mathrm{~m}^{2}$. Sorghum was sown at the seed rate of the area $\left(15 \mathrm{~kg} \mathrm{ha}^{-1}\right)$, and all the recommended and cultural practices in the area was applied during the growing season.

\section{Experimental Procedures}

\section{ETo and ETc Determination}

Primarily 20 years (1997-2016) climatic data includes monthly maximum and minimum temperature relative humidity, wind speed, sunshine hour's data was collected. Daily ETo (mm/day) values were computed from the collected data using FAO CropWat 8.0 windows model. The Kc-values was obtained from FAO Irrigation and Drainage Paper No. 56 (Allen et al., 1998). Then, crop water requirement was calculated from (FAO, 2010):

$\operatorname{ETc}(\mathrm{mm} /$ day $)=$ ETo $\mathrm{x} \mathrm{Kc}$

\section{Where:}

$\mathrm{ETc}=$ crop water requirement

ETo $=$ estimation of reference crop

evapotranspiration in $\mathrm{mm} /$ day and

$\mathrm{Kc}=$ crop coefficient

\section{Soil sampling and analysis}

For soil textural analysis and bulk density determination, disturbed and undisturbed soil samples were collected from $0 \mathrm{~cm}-20 \mathrm{~cm}, 20$ $\mathrm{cm}-40 \mathrm{~cm}$ and $40 \mathrm{~cm}-60 \mathrm{~cm}$ depth along the diagonal of the experimental field before planting respectively. Hydrometer method was employed for soil textural class analysis (Basu, 2011). The soil bulk density was determined by Oven dry method in the laboratory and calculated as the ratio of dry weight of the soil to known cylindrical core sampler volume (ICARDA, 2013).

$\mathrm{BD}=\frac{\mathrm{Ms}}{\mathrm{Vs}}$ $\ldots 1$

Where, Ms is the weight of oven dry soil in gram, and Vs is the volume of the same soil in $\mathrm{cm}^{3}$.

For the determination of moisture content at field capacity (FC) and permanent wilting point (PWP) soil samples was collected from $0 \mathrm{~cm}-20 \mathrm{~cm}, 20$ $\mathrm{cm}-40 \mathrm{~cm}$ and $40 \mathrm{~cm}-60 \mathrm{~cm}$ depth from the experimental field and determined in Ethiopian Construction, Design and Supervision Works Corporation soil laboratory in Addis Ababa. Then, calculated by using equation (Jaiswal, 2003).

$\theta m(\%)=(\mathrm{Wws}-\mathrm{Wds})^{*} 100$. 2 Wds

Where, $\theta m$ is mass based soil moisture content at FC or PWP (\%), Wws is weight of wet soil (gm) and Wds is weight of dry soil (gm). Soil infiltration rate was measured by using double ring infiltrometer in the field (Amreeta, 2014).

Selected soil chemical properties like $\mathrm{pH}$, electrical conductivity (EC), organic carbon (OC) and organic matter (OM) content were analyzed in Hawassa Agricultural Research Center soil laboratory. The organic carbon was analyzed with colorimetric method by the help of Spectrophotometer device in the laboratory and organic matter (OM) content was determined by multiplying organic carbon (OC) by constant factor 1.724 (Basu, 2011).

Hence, the total available water (TAW), stored in a unit volume of soil, is approximated by taking the difference between the water content at field capacity (FC) and at permanent wilting point (PWP). Therefore, the total available water was expressed by (Jaiswal, 2003):

$\mathrm{TAW}=\frac{(\mathrm{FC}-\mathrm{PWP})^{*} \mathrm{BD}^{*} \mathrm{Dz} .}{100}$

Where, TAW is total available water in $\mathrm{mm} / \mathrm{m}$, FC is field capacity and PWP is permanent welting point in percent (\%) on weight basis, BD is the bulk density of the soil in $\mathrm{gm} / \mathrm{cm}^{3}$ and $\mathrm{Dz}$ is the maximum effective root zone depth of sorghum in $\mathrm{mm}$.

The maximum root depth for sorghum was taken $1.5 \mathrm{~m}$. Then, RAW (mm) was computed from the expression (Allen et al., 1998):

$\mathrm{RAW}=\mathrm{P}$ .4

Where, $\mathrm{P}$ is in fraction for allowable soil moisture depletion for no stress $(p=0.55$ for sorghum) 
and TAW is total available water in $\mathrm{mm}$. Then, irrigation interval was computed from the expression (FAO, 2010:

Interval (days) $=\frac{\text { RAW }}{\text { ETc }}$

Where, RAW in $\mathrm{mm}$ which is equal to net irrigation depth $\left(\mathrm{d}_{\text {net }}\right)$ and ETc in $\mathrm{mm} /$ day.

Then, gross irrigation requirement (dg):

$\mathrm{dg}=\frac{\mathrm{dnet}}{\mathrm{Ea}}$

Where, $d_{g}$ in $m m$ and $E_{a}$ is the field irrigation application efficiency of a short, end diked furrow was taken as 60\% (Brouwer and Prins, 1989).

The amount of water applied to the experimental field was measured by 3 -inch Parshall flume. The time required to deliver the desired depth of water into each plot was calculated using the equation (Kandiah, 1981):

$\mathrm{t}=\frac{\mathrm{dg} \times \mathrm{A}}{6 \times \mathrm{Q}}$ .7

Where: $d_{g}=$ gross depth of water applied $(\mathrm{cm})$ $\mathrm{t}=$ application time $(\mathrm{min})$

$\mathrm{A}=$ Area of experimental plot $\left(\mathrm{m}^{2}\right)$ and $\mathrm{Q}=$ flow rate (discharge) $(\mathrm{l} / \mathrm{s})$

The irrigation depth was converted to volume of water by multiplying it with area of the plot (Valipour, 2012).

$\mathrm{V}=\mathrm{A}^{*} \mathrm{dg}$

Where: $V=$ Volume of water in $\left(\mathrm{m}^{3}\right)$

$\mathrm{A}=$ Area of plot $\left(\mathrm{m}^{2}\right)$

$\mathrm{d}_{\mathrm{g}}=$ Gross irrigation water applied (m)

\section{Economic water productivity}

Economic water productivity analysis was begun by considering the general relationship between the crop water use and crop yield per hectare of land at the different irrigation water application levels using the partial budget analysis. Partial budget is a method of organizing experimental data and information about the costs and benefits of various alternative treatments (CIMMYT, 1988).

Production costs were grouped into either fixed costs or variable costs (Galinato et al., 2011). Fixed costs for this study are those costs that are Table 1. Particle size distribution of the experimental site. not affected by amounts of irrigation water applied whereas variable costs are directly or indirectly affected by differences in the amounts of water applied. Economic analysis was done using the prevailing market prices during experimentation and at the time the crop was harvested. All costs and benefits were calculated on hectare basis in Ethiopian Birr (Birr/ha).

According to CIMMYT (1988), the average total yield was adjusted down wards by $10 \%$. This is for the reason that, the yields from the experimental plots and farmers' fields are different, thus average total yields should be adjusted downward. Based on this, the recommended level of $10 \%$ was adjusted from all 5 treatments to get the net yield. Then finally, adjusted yield was multiplied by field price to obtain gross field benefit of sorghum. In the season, local average market price for sesame grain in the study area was taken as 2000 Ethiopian birr per quintal and the price of irrigation water was taken as 1.00 Birr per $1.72 \mathrm{~m}^{3}$ of water.

\section{Statistical analysis}

Data analysis was under taken according to the data collected by using SAS software 9.1 for windows.

\section{Results and Discussion}

\section{Soil characterization of experimental site}

The result of laboratory soil analyses and field tests on physical and chemical characteristic, like, soil texture, BD, FC, PWP, soil $\mathrm{pH}$, electrical conductivity (EC), organic carbon (OC) content, organic matter (OM) content and soil infiltration rate were discussed below.

\section{Soil physical properties}

The result of the soil textural analysis from the experimental site was presented in Table 3 . The texture (40.8\% sand, $32.0 \%$ silt, $27.2 \%$ clay), (38\% sand, $38 \%$ silt, $24 \%$ clay), (45.6\% sand, $30.8 \%$ silt, $23.6 \%$ clay) at a depth of o $\mathrm{cm}-20$ $\mathrm{cm}, 20-40 \mathrm{~cm}, 40-60 \mathrm{~cm}$, respectively. Thus, according to USDA soil textural classification system, the soil of the experimental field could be classified as loam at all depths.

\begin{tabular}{|c|c|c|c|c|}
\hline $\begin{array}{c}\text { Depth } \\
(\mathrm{cm})\end{array}$ & Sand & Particle size distribution (\%) & Textural \\
\hline $\mathrm{O}-20$ & 40.8 & Clay & Silt & Class \\
\hline $20-40$ & 38.0 & 27.2 & 32.0 & Loam \\
\hline $40-60$ & 45.6 & 24.0 & 38.0 & Loam \\
\hline Average & 41.5 & 23.6 & 30.8 & Loam \\
\hline
\end{tabular}


Texture may affect the ease with which soil can be worked, the amount of water and air it holds and the rate at which water can enter and move through the soil. However, loam soils are best suited for sesame production because sand, silt and clay together provide desirable characteristics (EIAR, 2014). The bulk density (BD), total available water (TAW), water content at field capacity (FC) and permanent wilting point (PWP) values were presented in Table 2.

Table 2. Bulk densities, field capacity, permanent welting point and TAW of the soil.

\begin{tabular}{|c|c|c|c|c|c|}
\hline $\begin{array}{l}\text { Depth } \\
\text { (cm) }\end{array}$ & $\begin{array}{c}\mathrm{BD} \\
\left(\mathrm{g} / \mathrm{cm}^{3}\right)\end{array}$ & $\begin{array}{l}\mathrm{FC} \\
(\%)\end{array}$ & $\begin{array}{c}\text { PWP } \\
(\%)\end{array}$ & $\begin{array}{c}\text { TAW } \\
\text { (mm/depth) }\end{array}$ & $\begin{array}{c}\text { TAW } \\
(\mathrm{mm} / \mathrm{m})\end{array}$ \\
\hline $0-20$ & 1.26 & 29.31 & 12.78 & 41.66 & 208.28 \\
\hline $20-40$ & 1.28 & 28.13 & 12.46 & 40.11 & 200.55 \\
\hline $40-60$ & 1.31 & 26.04 & 10.72 & 40.15 & 200.74 \\
\hline Average & 1.28 & 27.83 & 11.98 & 40.64 & 203.18 \\
\hline
\end{tabular}

The average bulk density of the soil from experimental site showed a slight variation with depth. It varied from $1.26 \mathrm{~g} / \mathrm{cm}^{3}$ at the top root zone $(\mathrm{o}-20 \mathrm{~cm})$ to $1.31 \mathrm{~g} / \mathrm{cm}^{3}$ at the lower root zone layer $(40-60 \mathrm{~cm})$. The bulk density shows slight increase with depth. This could be because of slight increases of soil compaction with depth due to the weight of the overlying soil layer (Brady and Weil, 2002). However, the average soil bulk density is $1.28 \mathrm{~g} / \mathrm{cm}^{3}$ and which was in suitable range for crop growth (NRMD, 2011). The average total available water (TAW) of experimental site was found to be $203.2 \mathrm{~mm} / \mathrm{m}$, which was nearly upper range of loam soil (140 to $220 \mathrm{~mm} / \mathrm{m}$ ) (Majumdar, 2000).

The average soil infiltration rate and the cumulative intake curves based on the test result of the soil were presented. The basic infiltration rate of the soil was about $27.3 \mathrm{~mm} / \mathrm{hr}$. This rate of infiltration is the characteristic of loam soils (Brouwer and Heibloem, 1986).

\section{Soil chemical properties}

As indicated in Table 3, the average $\mathrm{pH}$ value of the experimental site through the analyzed depth was found to be nearly alkaline, with average value of 7.83 . It is suitable result, since sorghum can grow best in soils with $\mathrm{pH}$ range of 6.0 and 8.0 (EIAR, 2014). The soil had an average electrical conductivity of $0.182 \mathrm{dS} / \mathrm{m}$ through 60 $\mathrm{cm}$ profile which is below the threshold value for yield reduction, i.e. $1.2 \mathrm{dS} / \mathrm{m}$ (Smith et al., 2011).The OM content and OC content of the soil had average values of $2.67 \%$ and $1.55 \%$, respectively which indicates high soil fertility level $(\mathrm{OC}>1 \%)$ and suitable for vegetable production (Basu, 2011).

Table 3. Soil chemical properties of the experimental site.

\begin{tabular}{|c|c|c|c|c|}
\hline $\begin{array}{c}\text { Depth } \\
(\mathrm{cm})\end{array}$ & $\mathrm{pH}$ & $\begin{array}{c}\mathrm{ECe} \\
(\mathrm{dS} / \mathrm{m})\end{array}$ & $\begin{array}{c}\text { OC } \\
(\%)\end{array}$ \\
\hline O -20 & 7.69 & 0.210 & 1.43 & 2.46 \\
\hline $20-40$ & 7.93 & 0.173 & 1.65 & 2.85 \\
\hline $40-60$ & 7.87 & 0.178 & 1.58 & 2.72 \\
\hline Average & 7.83 & 0.182 & 1.55 & 2.67 \\
\hline
\end{tabular}

\section{Crop water requirement}

The total net and gross irrigation water applied on this experiment was $616.5 \mathrm{~mm} / \mathrm{season}$ and $1027.4 \mathrm{~mm} /$ season. During this field experiment implementation season, no rainfall was occurred in the area. Consequently, irrigation was the sole source of water for the crop throughout the whole growth period. Thus, net irrigation water requirement (IRn) was equal to crop water requirement (ETc).

\section{Sorghum grain yield}

Analysis of variance has shown that the grain yield of sorghum under treatment $\mathrm{T}_{3}$ and $\mathrm{T} 4 \mathrm{had}$ no statistically significant $(\mathrm{P}<0.05)$ difference with each other but had significant difference with $\mathrm{T} 1, \mathrm{~T} 2$ and $\mathrm{T} 5$. Numerically, the largest sorghum yield $3.88 \mathrm{t} /$ ha was recorded from $\mathrm{T}_{3}$ (100\% ASMD) and the smallest 2.79 t/ha was recorded from T1 (60\% ASMD) below Table 2. As observed in this study, when available soil moisture depletion level increases and decreases from $100 \%$ ASMD the sorghum grain yield was decreased. 
Table 4. Mean combined sorghum grain yield and water use efficiency.

\begin{tabular}{|c|c|c|}
\hline Treatments & $\begin{array}{l}\text { Grain yield } \\
\text { (t/ha) }\end{array}$ & $\begin{array}{l}\text { WUE } \\
\left(\mathrm{kg} / \mathrm{m}^{3}\right)\end{array}$ \\
\hline $\mathrm{T} 1=60 \% A S M D$ & $2.79 \mathrm{c}$ & $0.361 \mathrm{~d}$ \\
\hline T2 = 80\%ASMD & $3 \cdot 31 \mathrm{~b}$ & $0.504 c$ \\
\hline $\mathrm{T} 3=100 \% \mathrm{ASMD}$ & $3.88 \mathrm{a}$ & $0.6307 \mathrm{~b}$ \\
\hline $\mathrm{T}_{4}=120 \% \mathrm{ASMD}$ & $3.72 a$ & $0.672 \mathrm{ab}$ \\
\hline $\mathrm{T}_{5}=140 \% \mathrm{SMD}$ & $3.11 \mathrm{bc}$ & $0.756 a$ \\
\hline LSD (0.05) & 0.4059 & 0.0915 \\
\hline CV (\%) & 6.41 & 8.31 \\
\hline
\end{tabular}

Means with the same letter (s) are not significantly different at $P<0.05 ; L S D=$ least significant difference; $C V$ = Coefficient of variation.

\section{Water Productivity}

Analysis of variance has shown that water use efficiency of sorghum crop was significantly $(\mathrm{P}<0.05)$ affected by irrigation scheduling. In this study when to increase ASMD value from $100 \%$ then the water use efficiencies also increased while when to reduce from 100\% ASMD value then water use efficiency also reduced. This indicates that, the water use efficiency has direct relations with available moisture depletion level of the study area. The grain yield and water use efficiency of sorghum under treatments $\mathrm{T}_{3}$ and $\mathrm{T}_{4}$ had no significant differences. The tolerable sorghum grain yield and water use efficiency was obtained from treatment $\mathrm{T}_{4}$ (120\% ASMD) which was shown in figure 2 below. The intermediate irrigation regime may have higher water use efficiency than the most frequently irrigation regime. Therefore, it is better to select $120 \%$ ASMD to produce high grain yield of sorghum and to save water in the study area.

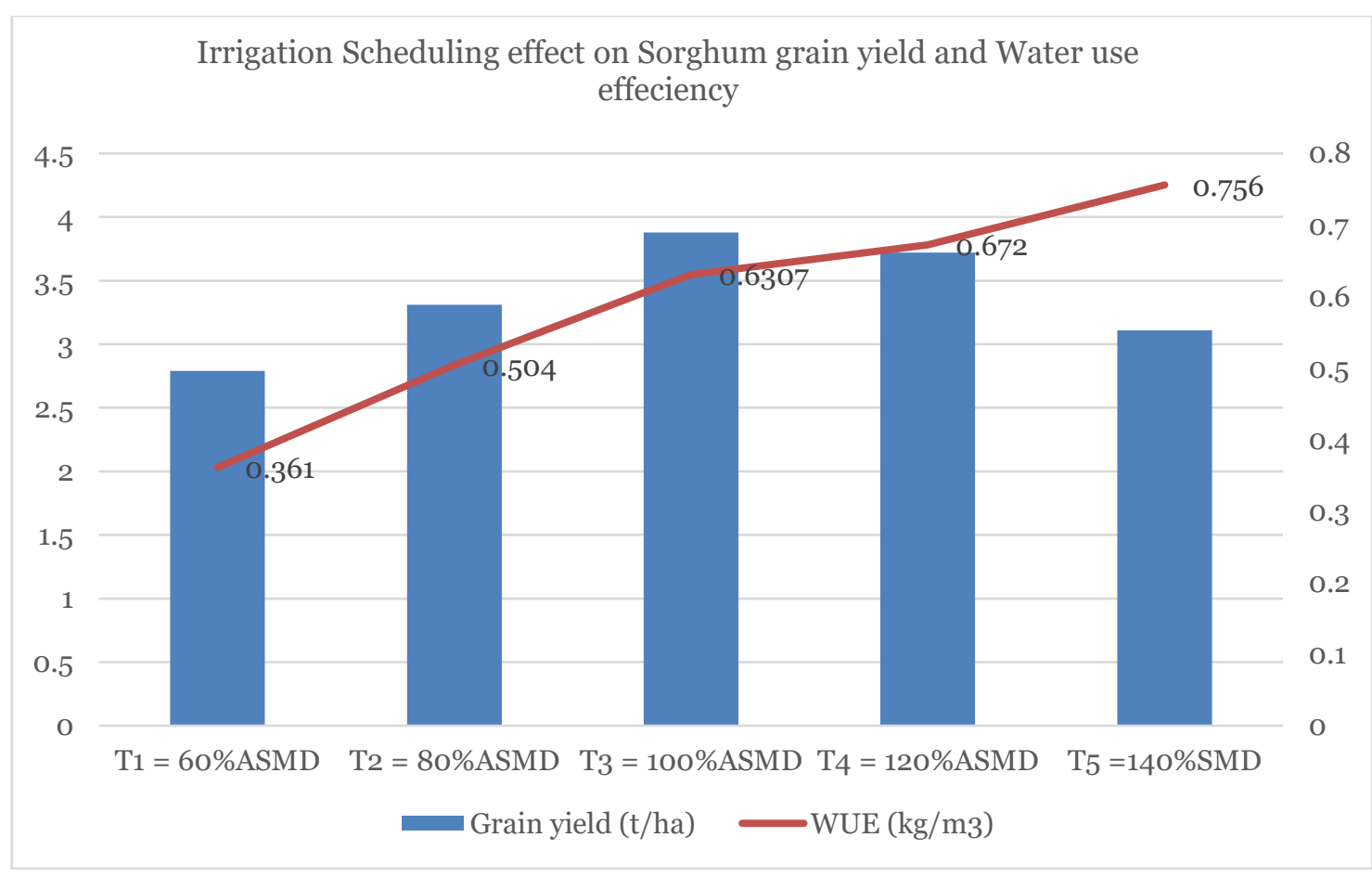

Fig. 2. Effect of irrigation scheduling on sorghum grain yield and water use efficiency.

\section{Economic Analysis}

The economic analysis was performed to determine how differences in amounts of irrigation water applied and the resulting yields affected the costs of production and the gross revenue. The variable costs considered in this study was water costs and labor costs others were fixed costs. The partial budget analysis revealed that, the highest net benefit of Birr 64157.02 per hectare with marginal return rate of $1108.88 \%$ was recorded from $\mathrm{T}_{3}$ and the lowest net benefit of Birr 46147.87 per hectare was recorded from T1 with lower cost as shown in the Table 5 below. 
Table 5. Economic analysis of sorghum production under different soil moisture depletion level.

\begin{tabular}{|c|c|c|c|c|c|c|c|c|c|}
\hline Treatments & $\begin{array}{c}\text { Irrigation } \\
\text { water applied }\end{array}$ & $\begin{array}{l}\text { Total } \\
\text { grain } \\
\text { yield }\end{array}$ & $\begin{array}{l}\text { Adjusted } \\
\text { yield }\end{array}$ & $\begin{array}{l}\text { Total } \\
\text { return }\end{array}$ & $\begin{array}{c}\text { Variable } \\
\text { cost }\end{array}$ & $\begin{array}{c}\text { Net } \\
\text { income }\end{array}$ & $\begin{array}{l}\text { Marginal } \\
\text { cost }\end{array}$ & $\begin{array}{c}\text { Marginal } \\
\text { benefit }\end{array}$ & MRR \\
\hline & $\left(\mathrm{m}^{3} / \mathrm{ha}\right)$ & (t/ha) & (t/ha) & (birr/ha) & (birr/ha) & (birr/ha) & & & (\%) \\
\hline $\begin{array}{l}\text { T1= } \\
60 \% A S M D\end{array}$ & 6155.00 & 2.79 & 2.51 & 50220.00 & 4072.13 & 46147.87 & 4072.13 & 46147.87 & 1133.26 \\
\hline $\begin{array}{l}\text { T2 = } \\
80 \% \text { ASMD }\end{array}$ & 8206.67 & $3 \cdot 31$ & 2.98 & 59580.00 & 4834.26 & $54745 \cdot 74$ & 762.14 & 8597.86 & 1128.13 \\
\hline $\begin{array}{l}\mathrm{T} 3= \\
100 \% A S M D\end{array}$ & 10258.33 & 3.88 & 3.49 & 69840.00 & 5682.98 & 64157.02 & 848.72 & 9411.28 & 1108.88 \\
\hline $\begin{array}{l}\mathrm{T} 4= \\
120 \% \text { ASMD }\end{array}$ & 12310.00 & 3.72 & 3.35 & 66960.00 & 6578.32 & 60381.68 & $895 \cdot 34$ & -3775.34 & -421.67 \\
\hline $\begin{array}{l}\mathrm{T}_{5}= \\
140 \% \text { ASMD }\end{array}$ & 14361.67 & 3.11 & 2.80 & 55980.00 & 7501.63 & 48478.37 & 923.31 & -11903.31 & -1289.20 \\
\hline
\end{tabular}

${ }^{*} A S M D=$ Available soil moisture depletion level, $M R R=$ Marginal Return Rate

The minimum acceptable marginal rate of return (MRR \%) should be between 50\% and 100\% CIMMYT (1988). Thus, the current study indicated that marginal rate of return is higher than $100 \%$ under treatments $\mathrm{T} 1, \mathrm{~T} 2$ and $\mathrm{T} 5$ (Table 5). This showed that all the treatments except $\mathrm{T} 4$ and $\mathrm{T} 5$ were economically important as per the MRR is greater than $100 \%$. However, T1 and T2 were practiced with frequent irrigation application when it compared to $100 \%$ ASMD that increased number of irrigation event that may have the most payments for labors and may cause soil salinity. Hence, the most economically attractive and environmentally accepted for small scale farmers with tolerable cost of production and higher net benefit was obtained by application of $\mathrm{T}_{3} \quad(100 \%$ ASMD) under conventional furrow irrigation system.

\section{Conclusions and Recommendations}

The purpose of this study was to evaluate the effect of different soil moisture depletion levels on yield and water use efficiency of sorghum crop. The total net and gross irrigation water applied on this experiment was $616.5 \mathrm{~mm} /$ season and $1027.4 \mathrm{~mm} /$ season respectively. The study results indicated that managing the available soil moisture depletion level had significant effect on both grain yield and water use efficiency of sorghum crop. Reducing the soil moisture depletion level by $40 \%$ from the recommended fraction (0.55) has significantly reduced the grain yield and water use efficiency. In other hand, by increasing the soil moisture depletion level with $20 \%$ over the recommendation of the total available soil moisture, the grain yield and crop water use efficiency was improved. The grain yield and crop water use efficiency of sorghum under 120\% ASMD had not significant difference with the recommended one (100\% ASMD). Under treatment $\mathrm{T}_{5}$ (140\% ASMD) the grain yield of sorghum was declined and water use efficiency was increased and this may be intolerable yield reduction in farmers level. Hence, the most economically attractive and environmentally accepted for small scale farmers with tolerable cost of production and higher net benefit was obtained by application of T3 (100\% ASMD) under conventional furrow irrigation system. Therefore, for this particular sorghum crop (teshale variety), it could be concluded that increased water saving and water productivity through irrigation at $100 \%$ ASMD under conventional furrow irrigation system can solve the problem of water shortage and would ensure the opportunity of further irrigation development in the study area and similar agro-ecology.

\section{References}

AGP (Agricultural Growth Program - II). 2015. Natural Resources Management Constraints Survey Reports in South Omo Zone, SNNPR. Southern Agricultural Research Institute, Jinka Agricultural Research Center; Unpublished.

Allen, R.G., Pereira, L.S., Raes, D. and Smith, M. 1998. Crop evapotranspiration: guidelines for computing crop water requirements. Food and Agricultural Organization (FAO), Rome. pp. 97-100.

Amreeta, C. 2014. Experimental study for determination of infiltration rate of soils in field using double ring infiltrometer: National Institute of Technology Rourkela769 oo8, Odisha, India. pp. 12-16.

Awulachew, Selesh Bekele; Teklu Erkossa and Regassa Namara. 2010. Irrigation potentialin Ethiopia, constraints and opportunities for enhancing the system. IWMI, Colombo, Sri Lanka.

Basu, P.K. 2011. Methods Manual Soil Testing in India: Department of Agriculture and Cooperation Ministry of Agriculture Government of India, New Delhi. pp. 63-67.

BOFED. 2015. SNNPRS Regional Statistical Abstract, Bureau of Finance and Economic Development, Hawassa, Ethiopia. pp. 103104. 
Brady, N.C. and R.R. Weil. 2002. The nature and Properties of Soils. $13^{\text {th }}$ ed. Person Education Ltd., USA. 96op.

Brouwer, C. and M. Heibloem. 1986. Irrigation Water Management: Irrigation Water Needs Training Manual no. 3. FAO. Rome, Italy.

Brouwer, C. and Prins, K. 1989. Irrigation Water Management: Irrigation Scheduling. Training manual no. 4. FAO. Rome, Italy.

CIMMYT. 1988. From agronomic data to farmer recommendations: An economics-training manual. Completely Revised Edition. International Maize and Wheat Improvement Center (CIMMYT), D.F, Mexico. pp. 123-125.

EIAR. 2014. Ethiopian strategy for sorghum: Hope for Sorghum and Millets ICRISAT. Ethiopian Institute of Agricultural Research, Bamako-Mali. p. 2.

FAO. 2010. CropWat for windows version 8.0. Food and Agricultural Organization (FAO), Rome, Italy. pp. 97-99.

Galinato, G.I., Lopez, R. and Islam, A. 2011. Fiscal spending and the environment: Theory and empirics. J. Environ. Econ. Manage. 62(2): 180-198.

https://doi.org/10.1016/j.jeem.2011.03.001

Geerts, S. and Raes, D. 2009. Deficit irrigation as an on-farm strategy to maximize crop water productivity in dry areas. Agril. Water Manage. 96(9): 1275-1284. https://doi.org/10.1016/j.agwat.2009.04.009

ICARDA. 2013. Methods of Soil, Plant, and Water Analysis: A manual for the West Asia and North Africa region. Third Edition-George Estefan, Rolf Sommer, and John Ryan. International Center for Agricultural Research in the Dry Areas, Aleppo. pp. 192196.

Jaiswal, P.C. 2003. Soil, plant and water analysis. Kalyani puplishers. New Delhi, India. p. 156.

Kandiah, A. 1981. A guide for measurement of irrigation water using Parshall flumes and siphons. Technical Bulletin no.1 Irrigation Agronomy Section Melka Werer Research Station Institute of Agricultural Research, FAO irrigation Specialist. Addis Ababa. p. 87.

Majumdar, D.K. 2000. Irrigation Water Management: Module 3 Irrigation Engineering Principles Version 2 CE IIT, Kharagpur by Prentice Hall of India. p. 487.
Mdemu, M.V., Rodgers, C., Vlek, P.L.G. and Borgadi, J.J. 2008. Water productivity (WP) in reservoir irrigated irrigation system in the upper east region (UER) of Ghana. Physics Chem. Earth. 34(4-5): 324-328. https://doi.org/10.1016/j.pce.2008.08.006

Mekonen, A. 2011. Deficit irrigation practices as alternative means of improving water use efficiencies in irrigated agriculture: Case study of maize crop at Arba Minch, Ethiopia. African J. Agril. Res. 6(2): 226-235. https://doi.org/10.5897/AJAR09.118

Mugoro, T., Assefa, S. and Getahun, A. 2020. Molecular markers: Effect of deficit irrigation on yield and water productivity of Onion (Allium cepa L.) under conventional furrow irrigation system, in Bennatsemay Woreda, Southern Ethiopia. J. Agril. Biol. Eng. 1(1): o02-013. Retrieved from

https://www.premierpublishers.org/jabe/021220198775

NRMD (Natural Resources Management Directorate). 2011. Natural Resource Sector and the Ministry of Agriculture, Addis Ababab, Ethiopia. By Deutsche Gesells chaft für Internationale Zusammenarbeit (GIZ) $\mathrm{GmbH}$ on behalf of the German Government.

Smith, R., Biscaro, A., Cahn, M., Daugovish, O., Natwick, E., Nunez, J. Takele, E. and Turini, T. 2011. Fresh-market bulb onion production in California. Publication 7242. University of California, Agricultural and Natural Resource Center. California. 6p. https://doi.org/10.3733/ucanr.7242

Valipour, M. 2012. Determining possible optimal values of required flow, nozzle diameter, and wetted area for linear traveling laterals. Int. J. Eng. Sci. 1(1): 37-43. Retrieved from https://www.theijes.com/papers/v1i1/Ho11037043.pdf

Wale, A. and Girmay, G. 2019. Determination of irrigation regime for hot pepper (Capsicum annum L.) in dry-land areas of Wag- Himra, North Eastern Amhara, Ethiopia. Arch. Agric. Environ. Sci. 4(1): 101-108. https://doi.org/10.26832/24566632.2019.0401016

WDR (World Development Report). 2003. Sustainable Development in a Dynamic World: Transforming Institutions, Growth, and Quality of Life, World Bank. pp. 123126. 